THE LOW COUNTRIES HISTORY YEARBOOK ACTA HISTORIAE NEERLANDICAE 


\section{EDITORIAL BoARD:}

I. Schöffer (Leiden); Johanna A. Kossmann (Groningen); J.R. Bruijn (Leiden); J.H. van Stuijvenberg (Amsterdam); R. Van Uytven (Antwerp); Els Witte (Brussels).

\section{EDITORIAL ADDRESS:}

Nederlands Historisch Genootschap

Postbox 90406

2509 LK The Hague, The Netherlands. 


\section{THE LOW}

COUNTRIES Acta

HISTORY

Historiae

YEARBOOK Neerlandicae

\section{2}
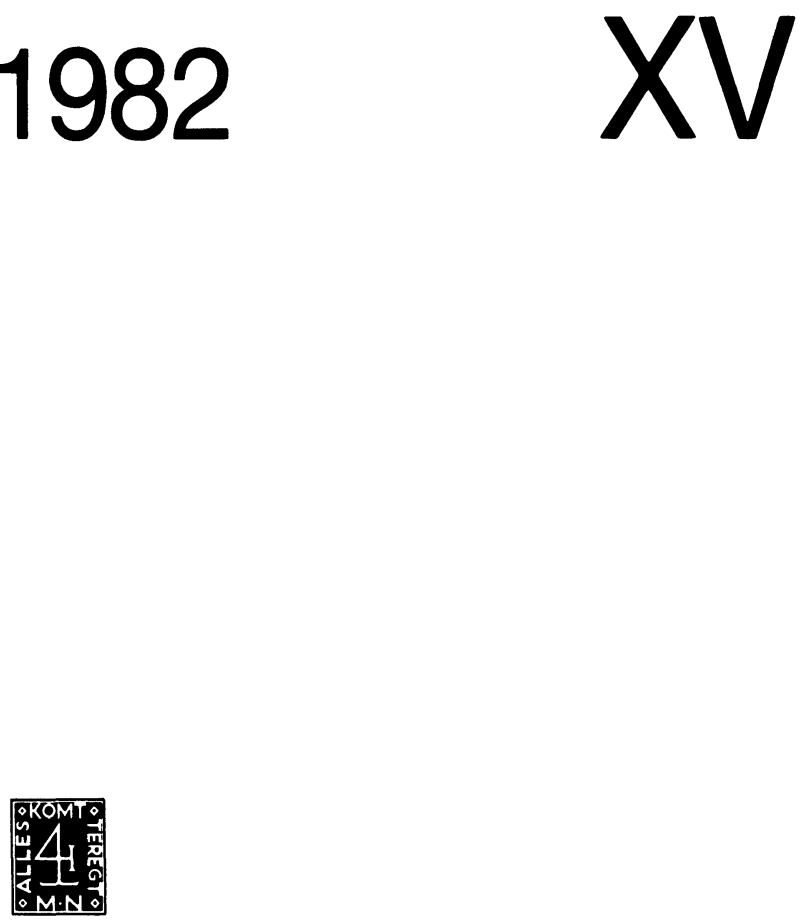

MARTINUS NIJHOFF - 1982 
ISBN-13: 978-94-009-6936-0

e-ISBN-13: 978-94-009-6934-6

DOI: $10.1007 /$ 978-94-009-6934-6

(c) 1982 Uitgeverij Martinus Nijhoff, Lange Voorhout 9 , Den Haag

Softcover reprint of the hardcover Ist edition 1982

Behoudens uitzondering door the Wet gesteld mag zonder schriftelijke toestemming van de rechthebbende(n) op het auteursrecht, t.w. de uitgeefster van deze uitgave, door de rechthebbende( $n$ ) gemachtigd namens hem (hen) op te treden, niets uit deze uitgave worden verveelvoudigd en/of openbaar gemaakt door middel van druk, fotokopie, microfilm of anderszins, hetgeen ook van toepassing is op de gehele of gedeeltelijke bewerking.

De uitgeefster is met uitsluiting van ieder ander gerechtigd de door derden verschuldigde vergoedingen voor kopiëren, als bedoeld in artikel 17 lid 2, Auteurswet 1912 en in het K.B. van 20 juni 1974 (Stb. 351) ex artikel $16 b$ Auteurswet 1912, te innen en/of daartoe in en buiten rechte op te treden.

No part of this book may be reproduced in any form by print, photoprint, microfilm or any other means without written permission from the publisher. 


\section{TABLE OF CONTENTS}

Preface

J. De Belder, Changes in the socio-economic status of the Belgian nobility in the nineteenth century

R.W.J.M. Bos, Industrialization and economic growth in the Netherlands during the nineteenth century: an integration of recent studies

G. Teitler, A 'New' and an 'Old Trend'. Military thinking in the Netherlands and the Dutch East around the turn of the century

C.B. Wels, Van Karnebeek's break with tradition

C. FASSEUR, A cheque drawn on a failing bank: the address delivered by Queen Wilhelmina on 6th/7th December 1942

A. Meynen, The Great Strike of 1960-61: its economic and socio-political background

C.R. EMERy AND J.A. Kossmann, editors, Survey of recent historical works on Belgium and the Netherlands published in Dutch 


\section{Preface}

The present volume, number 15 of the Acta Historiae Neerlandicae - which have been appearing since 1978 under the title The Low Countries History Yearbook - is the last of the series. Economic reasons force the publishers to discontinue it. This is a matter for regret. Both the editors of the Yearbook and the board of the Nederlands Historisch Genootschap, under the auspices of which it has been published, are convinced that the books serve a useful purpose. We hope that in the future more favourable circumstances will enable Dutch and Flemish historians to start a second series.

We feel, however, that the Yearbook should not be allowed to disappear completely. In our opinion, one of its most attractive features has been the 'Survey of recent historical works on Belgium and the Netherlands published in Dutch.' It is the intention of the Nederlands Historisch Genootschap to seek means to continue this in another form, probably in that of pamphlets appearing every two years and written by the same, or a similar, group of experts. In that way we may be able to provide a useful service to our colleagues abroad.

It is with regret and a certain sadness that we, the editors, stop our work. Before taking leave, however, we wish to thank all contributors and translators - they make an impressive list - for the helpfulness and kindness which have enabled us to build up what we consider, with some satisfaction, to have been a distinguished and wellknown series of books.

J.R. Bruijn

Johanna A. Kossmann

I. Schöffer

J.H. van Stuijvenberg

R. Van Uytven

Els Witte 